\title{
IAMJ
}

INTERNATIONAL

AYURVEDIC

MEDICAL JOURNAL

\section{AN AYURVEDIC MANAGEMENT OF SPINAL MUSCULAR ATROPHY (SMA) - A CASE STUDY}

\author{
Raheena $B^{1}$, Shaila Borannavar ${ }^{2}$, Ananta S Desai ${ }^{3}$ \\ ${ }^{1}$ PG Scholar, Department of Panchakarma, Government Ayurveda Medical College, Bangalore, Karnataka, India \\ ${ }^{2}$ Associate Professor, Department of Panchakarma, Government Ayurveda Medical College, Bangalore, \\ Karnataka, India \\ ${ }^{3}$ HOD Department of Panchakarma, Government Ayurveda Medical College, Bangalore, Karnataka, India
}

Corresponding Author: raheena.baligar.786@gmail.com

https://doi.org/10.46607/iamj4309112021

(Published Online: November 2021)

Open Access

(C) International Ayurvedic Medical Journal, India

Article Received: 02/11//2021 - Peer Reviewed: 10/11/2021 - Accepted for Publication: 12/11/2021

\section{Check for updates}

\begin{abstract}
Spinal Muscular Atrophy (SMA) is the second leading genetic disorder inherited in the autosomal recessive pattern due to the absence of the SMN1 gene characterized by loss of motor neurons and progressive muscle wasting, often leading to dependent life and decreased life span. In Ayurveda, this condition can be considered as Kulaja Vyadhi wherein the patient's Mamsa and Snayu is affected by Vata. This can be regarded as Mamsa-Snayugata Sarvanga Vata. It is said that Prakruta Vata dosha is the life, it is the strength, it is the sustainer of the body, it holds the body and life together. If it is Vikruta it produces Sankocha, Khanja, Kubjatva, Pangutva, Khalli and Soshana of Anga. So, in this disease aggravated Vata does the vitiation of Mamsa and Snayu thus leading to Soshana of both, resulting in Stambha, Nischalikarana of Avayava. A 21years female patient was admitted to our I.P.D with c/o of reduced strength in all four limbs leading to the inability to walk and to maintain erect posture during standing and sitting positions. Based on Ayurvedic principles the patient was initially subjected to Avaranahara Chikitsa followed by Brimhana line of management.
\end{abstract}

Keywords: Mamsagata vata, Snayugata vata, Sarvanga vata, Spinal muscular atrophy (SMA) 


\section{INTRODUCTION}

It is a human outlook to dream of begetting healthy \& flawless offspring, but it is unfortunate to have increased incidences of the unhealthy pediatric population with irremediable major neurological disabilities. The management of such ailments has become rather confusing to the present-day clinicians and apparent remedies if present is highly not sure \& expensive.

Motor neuron diseases or motor neurone diseases (MNDs) are a group of rare neurodegenerative disorders that selectively affect motor neurons, the cells which control voluntary muscles of the body. They include amyotrophic lateral sclerosis (ALS), progressive bulbar palsy (PBP), pseudobulbar palsy, progressive muscular atrophy (PMA), primary lateral sclerosis (PLS), spinal muscular atrophy (SMA) and monomeric amyotrophy (MMA), as well as some rarer variants resembling ALS. ${ }^{1}$

Spinal muscular atrophy (SMA) is a group of hereditary diseases that progressively destroys motor neurons - nerve cells in the brain stem and spinal cord that control essential skeletal muscle activity such as speaking, walking, breathing, and swallowing, leading to muscle weakness and atrophy. Motor neurons control movement in the arms, legs, chest, face, throat, and tongue. When there are disruptions in the signals between motor neurons and muscles, the muscles gradually weaken, begin wasting away and develop twitching (called fasciculation) $)^{2}$

Spinal muscular atrophy is due to an abnormality (mutation) in the SMN1 gene which encodes SMN, a protein necessary for the survival of motor neurons. Loss of these neurons in the spinal cord prevents signalling between the brain and skeletal muscles. Another gene, $S M N 2$, is considered a disease-modifying gene, since usually the more the SMN2 copies, the milder is the disease course. The diagnosis of SMA is based on symptoms and confirmed by genetic testing. ${ }^{3}$

In an age of onset, symptoms and rate of progression there is wide variability. To account for these differences, the chromosome 5 SMA often is classified into types 1 to 4 . Approximately the degree to which motor function is affected depends on the age at which the onset of SMA symptoms occurs. The earlier the age of onset, the greater the effect on motor function. Children who present symptoms at birth or in infancy typically have the lowest level of functioning (type 1). SMA onset in children (types 2 and 3), teens or adults (type 4) generally relates to increasingly higher levels of motor function. Other rare forms of SMA (nonchromosome 5) are caused by mutations in genes other than $\mathrm{SMN}^{4}$.

SMA is the second most common serious autosomal recessive disorder after cystic fibrosis, with an estimated incidence of 1 in 6,000 to 1 in 10,000 live births, with a carrier frequency of $1 / 401 / 60(2,3)$. Although no medical treatment is available, investigations have elucidated possible mechanisms underlying the molecular pathogenesis of the disease.

If SMA effects appear after a child's first 18 months of life. Some people with type 3 don't have signs of disease until early adulthood. Type 3 symptoms include mild muscles weakness, difficulty walking and frequent respiratory infections. Over time, symptoms can affect the ability to walk or stand. Type 3 SMA doesn't significantly shorten life expectancy.

One to one correlation of an all-modern disease to the Ayurvedic disease is not possible ${ }^{5}$. But based on the etiopathogenesis, and symptomology it can be considered as 'Mamsa Snayugata Sarvanga Vata'6 as well as Kulaja Vyadhi as bheeja gata margavaroda janyavata Vyadhi ${ }^{7}$ under the conglomeration of Vata Vyadhi (Neurological Disorder) that have an overlap of the symptoms of SMA. Contributory factors like inappropriate Ritu (ovulation cycle), Kshetra(uterus), Ambu (amniotic fluid), Bheeja (Sperm and Ovum), presence of garbopagatakara bhavas (activities or substance which are not favourable for growth and survival of foetus $)^{8}$ etc... and Vatakara Ahara Vihara all these factors may have an unwanted effect on child impeding its normal growth and development subsequently leading to many diseases, deformities and even death. Hence a formulated Ayurvedic protocol can improve the condition of SMA patients, providing a quality life minimizing their dependency. 


\section{CASE REPORT:}

Basic information of the patient:

A 21-year Female patient visited GAMC Bangalore with complaints of reduced strength in all four limbs leading to inability to walk and maintain erect posture during standing and sitting positions. She was a Hindu by religion and was born to middle class, illiterate, consanguineous parents

\section{Chief complaints (Pradhana vedana visesha):}

Reduced strength in all four limbs, inability to walk and maintain erect position during standing and sitting position for 7 years.

\section{Associated complaint:}

$\mathrm{B} / \mathrm{L}$ shoulder joint pain and B/L knee joint pain, stiffness and heaviness all over the body along with spandana (fasciculation), slight muscle wasting in left LL since 5years

\section{History of present illness (vedana vyadhi vrittanta):}

A female patient aged about 21 years, was healthy before 5 years, she gradually developed pain in right UL and Left LL and then the pain started to right LL and left UL after that she felt weakness in all four limbs lead to difficulty in walking, she consulted orthopediatrician there they have advised doing MRI and CPK, in that MRI report was normal, CPK is elevated. There they have instructed medicine for 6 month, she took medicine for 4 months. Symptoms are gradually increased after that she didn't consult any doctor for 4 years and for better management she had admitted to our hospital.

History of past illness (Purva Vyadhi Vrittanta):

Nothing significant

Treatment history: The patient took allopathic treatment for 4 months then she discontinued the medication (Detail history is not known) and come to GAMC Bangalore for better relief.

Family history (Kualja Vrittanta): Parents had consanguineous marriage \& Patient's Mother and Young brother was known to have same symptoms both have died

History of consanguineous marriage is found

Personal history (Vaiyaktika Vrittanta):

Diet: Non-vegetarian

Appetite: Good

Micturition: 4-5 times/day

Bowel: Once /Day

Habits: Nothing Specific

Examination: Vitals were normal, no abnormalities were found in the cardiovascular system, respiratory system, gastrointestinal system.

Table 1: Rogi Pariksha

\begin{tabular}{|l|l|}
\hline Prakriti & Kapha pitta \\
\hline Sara & Pravara \\
\hline Samhanana & Madhyama \\
\hline Pramana & Madhyama \\
\hline Satmya & Madhyama \\
\hline Satva & Madhyama \\
\hline Ahara Sakti & Pravara \\
\hline Vyayama Shakti & Avara \\
\hline Vyayah & Baala $(21$ years $)$ \\
\hline
\end{tabular}

Table 2: Samprapti Ghataka

\begin{tabular}{|l|l|}
\hline Nidana & Bheeja Dosha \\
\hline Dosha & Vata (Vyana) (Chala guna) \\
\hline Dushya & Mamsa, Snayu \\
\hline Agni & Bhutagni and Dhatvagni \\
\hline Roga Marga & Madhyama \\
\hline Adhistana & Shiras \\
\hline Srotas & Mamsa \\
\hline Sroto Dushti & Sanga(abstractions) \\
\hline Vyakta Sthana & Sarva Shareera \\
\hline
\end{tabular}


Central Nervous System Examination:

HMF: Conscious \& Well oriented

Motor System Examination:

- Muscle bulk was Normal

- The tone was Normotonia in all four limbs

- Power was 1/5 in all the four limbs

- Deep tendon reflexes are absent

Sensory system Examination: Intact

Investigations:

MRI of whole spine finding was normal

C.P.K. (Creatine Phosphokinase): 905.8U/L

\section{Differential Diagnosis:}

Acute flaccid paralysis

DMD

Poliomyelitis

Gullian Barre Syndrome

Amyelotropic lateral sclerosis

Diagnosis: The patient was diagnosed with Spinal Muscular Atrophy

Treatment Protocol: Treatment protocol comprises 58 days which includes external procedures and internal oral medication

Table 3: Treatment is given

\begin{tabular}{|c|c|c|}
\hline Dates & Treatment given & Improvements observed \\
\hline $9 / 2 / 2021$ to $16 / 2 / 2021$ & $\begin{array}{l}\text { Sarvanga abhyanga with Mahanarayana taila } \\
\text { f/b Dhashamoolakashaya Seka }\end{array}$ & $\begin{array}{l}\text { Heaviness in the body got reduced up to } \\
20 \%\end{array}$ \\
\hline $17 / 2 / 2021$ to $26 / 2 / 2021$ & $\begin{array}{l}\text { Sthanika abhyanga with Sahacharadi taila } \mathrm{f} / \mathrm{b} \\
\text { Sthanika Udwarthana }\end{array}$ & $\begin{array}{l}\text { Stiffness and heaviness in the body got re- } \\
\text { duced up to } 40 \%\end{array}$ \\
\hline $27 / 2 / 2021$ to $2 / 3 / 2021$ & Oral medications only & \\
\hline $3 / 3 / 2021$ to $9 / 3 / 2021$ & Sthanika abhyanga with $f / b$ Patrapinda Sweda & Muscle bulk in the left LL have increased \\
\hline $10 / 3 / 2021$ to $18 / 3 / 2021$ & $\begin{array}{l}\text { Sarvanga abhyanga with Sahacharadi taila f/b } \\
\text { Dashamoolakashaya seka }\end{array}$ & $\begin{array}{l}\text { Spandana (fasciculations) in the B/L shoul- } \\
\text { der and thigh got reduced }\end{array}$ \\
\hline $19 / 3 / 2021$ to $25 / 3 / 2021$ & Oral medication only & \\
\hline $26 / 3 / 2021$ to $1 / 4 / 2021$ & $\begin{array}{l}\text { Sarvanga abhyanga with Dhanwantaram taila } \\
\text { f/b Dhanyamla dhara }\end{array}$ & $\begin{array}{l}\text { Stiffness and heaviness in the body got re- } \\
\text { duced up to } 60 \%\end{array}$ \\
\hline
\end{tabular}

Internal medication (Abhyantara aushada Prayoga):

1) Bhrihat Vata Chintamani (2 tab two times after food in a day)

2) Ashwagandha ksheera paka (After food $20 \mathrm{ml}$ two times a day)

3) Vatagajankusha rasa (After food 3 tab three times in a day)

4) Lashunadi vati (After food 2 tab two times in a day)

Pathya:

Balya, Brimhana, Mamsa Rasa, Shali dhyana, Yoosha. Apathya:

Ruksha, Asuchi, Abhiyandi, Vatakara Ahara and vihara

\section{DISCUSSION}

Understanding SMA - an Ayurvedic perspective/ insight

Diagnosis: SMA can be correlated to 'Mamsa Snayugata Sarvangavata,

Vata vitiation leads to the movement (gamana) of Vata in different Dhatus or Margavarodha. Margavarodha causes Dhatu sosha (karotyavatamargatvaad rasadi kopasoshayet $)^{9}$

The vitiated vata in the body will vitiate the Garbha, Shukra, Arthavam (Bija) (Garbha sukra rajonasha spandanam gatrasuptataa)

In the Bijas the affected part in the bija correspondingly affects a similar part of the fetus (yasya yasya havayavasya bhije bijabage ${ }^{10}$ leading to Vata Sanchaya and Prakopa which causes Sthanasamsraya in Mamsa and Snayu due to Kha Vaigunya leads to Mamsa Snayugata Sarvangavata. 
As per modern science, it is a genetic disorder in which the motor neurons in the anterior horn of the spinal cord are damaged subsequently motor functions (movements) are affected because of the loss of alpha motor neurons. Vata is responsible for both sensory and motor functions (sarva hi cheshtah vatena sa pranah praninam smritah) in the body. In this condition, the task of vata is affected due to the vitiation of vata.

\section{Role of Physiotherapy:}

(Lagavam karma ...vyayamadupajate ${ }^{11}$ physiotherapy is done to improve functional mobility, to strengthen and stimulate the growth of muscles, to improve the ability to move parts of the body, to prevent joint stiffness and muscle atrophy (wasting of the muscles) of the limbs.

The treatment protocol planed for the present patient and executed was based on the following principle.

To remove margavarodha (Kapha avarana) if any and followed by kevala or samanya vata chikitsa.

Ayurvedic treatment for SMA is primarily aimed at arresting/ slowing down the progression of illness and helping alleviate the symptoms. However, in many cases, an attempt was made to reactivate the neurons in the spinal column.

The vitiated Vata produces specific diseases because of the specific nature of the causative factors and the seats of manifestation, specific treatment should be given based on-site, dhushyas etc. as per person.

A common line of treatment for vitiated Vata- Ghee, oil, muscle fat, bone marrow, seka, abhyanga, vasti, snigdha, sweda, to stay in a windless place, cover with blankets, mamsa rasa, milk food and sweet, sour and salty food. All these will be good for Vata vitiated persons.

Treatment Limits the progress of the motor neuron degeneration, optimizing neuron activity, Preventing further complications by Vathanulomanam \& rasayanam.

Dhatvagni niyamana is achieved which further Stops further muscle atrophy, promote muscle tonicity by Dhatu poshana and Improves tissue immunity.
Abhyanga, Patrapinda sweda, Dhanyamla dhara helps in the fortification of neuromuscular coordination (stimulating the nerve endings by nourishing thus maintaining proper motor functions).

\section{CONCLUSION}

In this patient, a remarkable improvement in muscle tone, power \& regaining back of a few motor skills with our interventions in a short span gives hope of further progress of symptoms and helps to improve quality of life (QOL). Treatment intervention in the early stages helps in getting a major benefit at later ages. Previously it was believed that neurons do not repair or rejuvenate after injury, but the new concept of neuroplasticity says that CNS can repair their neurons by axonal sprouting to take over the function of damaged neurons. Going by the results of this case study, we can conclude - Ayurvedic modality of treatment is helpful for better management of SMA. Through a Multi-disciplinary approach - Ayurveda as baseline therapy associated with other evolving therapies like physiotherapy, occupational, behaviour therapies would certainly do a lot for the improvement of QOL. Hence, further research can be done on a larger sample.

\section{REFERENCES}

1. https://en.m.wikipedia.org/wiki/Motor_neuron_disease

2. https://www.ninds.nih.gov/Disorders/Patient-Caregiver-Education/Fact-Sheets/Spinal-Muscular-Atrophy-Fact-Sheet

3. https://en.m.wikipedia.org/wiki/Spinal_muscular_atrophy

4. https://www.sciencedirect.com/science/article/abs/pii/S0140673608609216\#! Mitchell R Lunn BS, Dr Ching Hwang MD - Spinal muscular atrophyThe Lancet- Volume 371.

5. Agnivesha, Charaka, Dridhabala, Chakrapani, Charaka Samhita, - Chaukhamba Prakashana, Varanasi; 2007Sutra sthana- Trishotiya adhyaya-18/44

6. Trikamji Y, - Ayurveda dipika, Chaukhamba Prakashana; 2009.Agnivesha, Charaka, Dridhabala, Chakrapani, Charaka Samhita, Chikitsa sthana28/25,32,35. 
7. Agnivesha, Charaka, Dridhabala, Chakrapani, Charaka Samhita, - Chaukhamba Prakashana, Varanasi; 2007Sharira sthana- Mahati garbhavakranti adhyaya-4/18. P. 320

8. Trikamji Y, Achrya, Sushruta, Sushruta Samhita, Shareera Sthana-2/33, Varanasi; Chaukhamba Sanskrit Sansthana; 2009.P.348

9. Charaka Samhita with critical exposition based on Cakrapanidatta's Ayurveda dipika by RK sharma, and Bhagwan Dash- Chowkhambha Sanskrit series office , Varanasi-reprint-2016 - Chikitsa Sthana28/61.

10. Agnivesha, Charaka, Dridhabala, Chakrapani, Charaka Samhita, - Chaukhamba Prakashana, Varanasi; 2007Sharira sthana- Mahati garbhavakranti adhyaya-4/30

11. Agnivesha, Charaka, Dridhabala, Chakrapani, Charaka Samhita, - Chaukhamba Prakashana, Varanasi; 2007Sutra sthana- Navegandharaniya adhyaya-7/32.

\section{Source of Support: Nil}

\section{Conflict of Interest: None Declared}

How to cite this URL: Raheena B et al: An Ayurvedic Management Of Spinal Muscular Atrophy (SMA) - A Case Study. International Ayurvedic Medical Journal \{online\} 2021 \{cited November 2021\} Available from: http://www.iamj.in/posts/images/upload/2897_2902.pdf 